\title{
Novel liver-specific cholic acid-cytarabine conjugates with potent antitumor activities: Synthesis and biological characterization
}

\author{
Dan-qi CHEN, Xin WANG, Lin CHEN, Jin-xue HE, Ze-hong MIAO, Jing-kang SHEN* \\ State Key Laboratory of Drug Research, Shanghai Institute of Materia Medica, Chinese Academy of Sciences, Shanghai 201203, \\ China
}

\begin{abstract}
Aim: Cytarabine is an efficient anticancer agent for acute myelogenous leukemia, but with short plasma half-life and rapid deamination to its inactive metabolite. The aim of this study was to design and synthesize novel cholic acid-cytarabine conjugates to improve its pharmacokinetic parameters.

Methods: The in vitro stability of novel cholic acid-cytarabine conjugates was investigated in simulated gastric and intestinal fluid, mouse blood and liver homogenate using HPLC. The portacaval samples of the conjugates were examined in male Sprague-Dawley rats using LC/MS, and in vivo distribution was examined in male Kunming mice using LC/MS. Antitumor activities were tested in HL60 cells using MTT assay.

Results: Cholic acid-cytarabine compounds with four different linkers were designed and synthesized. All the four cholic acid-cytarabine conjugates could release cytarabine when incubated with the simulated gastric and intestinal fluid, mouse blood and liver homogenate. The conjugates $\mathbf{6}, \mathbf{1 2}$, and $\mathbf{1 6}$ were present in the portacaval samples, whereas the conjugate 7 was not detected. The conjugates 6 and 16 showed high specificity in targeting the liver (liver target index 34.9 and 16.3, respectively) and good absorption in vivo, as compared with cytarabine. In cytarabine-sensitive HL60 cells, the conjugates 6, 12, and 16 retained potent antitumor activities. Conclusion: Three novel cholic acid-cytarabine conjugates with good liver-targeting properties and absorption were obtained. Further optimization of the conjugates is needed in the future.
\end{abstract}

Keywords: cytarabine; cholic acid; liver; antitumor drug

Acta Pharmacologica Sinica (2011) 32: 664-672; doi: 10.1038/aps.2011.7; published online 25 Apr 2011

\section{Introduction}

$1-\beta$-D-Arabinofuranosylcytosine (cytarabine, Ara-C) is an efficient anticancer agent for acute myelogenous leukemia ${ }^{[1,2]}$. However, its usefulness is limited by its short plasma half-life and rapid deamination to the biologically inactive metabolite, $1-\beta-D$-arabinofuranosyluracil (Ara-U) by cytidine deaminase ${ }^{[3]}$. Cytidine deaminase is a ubiquitous enzyme found in high concentrations in the intestine, liver, spleen, and kidneys ${ }^{[4]}$. When administered by iv, systemic elimination is biphasic with an initial plasma half-life $\left(t_{1 / 2 \alpha}\right)$ of 7-20 min and a terminal half-life $\left(t_{1 / 2 \beta}\right)$ of $2-3 \mathrm{~h}^{[5]}$. Cytarabine derivatives and conjugates have been designed with the intention of increasing its stability and lipophilicity as well as avoiding rate-limiting cytarabine phosphorylation while maintaining its biological

\footnotetext{
* To whom correspondence should be addressed. E-mail jkshen@mail.shcnc.ac.cn

Received 2010-11-02 Accepted 2011-01-18
}

activity $^{[6]}$. For example, ancitabine (cyclocytidine), enocitabine and fostabine have been used clinically in Japan (Figure 1) ${ }^{[7-9]}$.

The conjugation of cytarabine through the formation of a bond with its amino group at the $\mathrm{N}^{4}$ position may protect the amino group from deamination and change the pharmacokinetic parameters of the cytarabine because new molecules are often more lipophilic. Behenoyl-Ara-C (Enocitabine, 4), one of the $N^{4}$-acyl derivatives of saturated fatty acids, has been found to be superior to its parent compound, cytarabine, likely because of the resistance to cytidine deaminase and the liberation of Ara-C over a period of time ${ }^{[8]}$. $N^{4}$-peptidyl-AraC, like $L$-valyl-Ara-C, was reported to increase cellular uptake of cytarabine through the involvement of various transporters $^{[10]}$. Relatively high activity of cytarabine conjugates was achieved through the coupling of amino groups of cytarabine with carboxyl groups of polysaccharide molecules (eg, polygalacturonic acid (PGA) and carboxymethylated yeast beta$D$-glucan (CMG)); the in vitro antileukemic activity of these 
conjugates was comparable or higher than the activity of nonconjugated/free cytarabine combined with a polysaccharide ${ }^{[11]}$ (Figure 2).

The 5'-hydroxyl group is essential for the biological activity

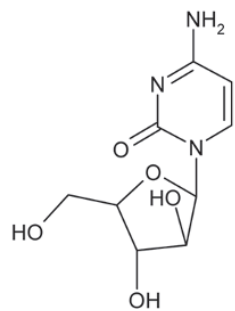

Cytarabine, Ara-C

1

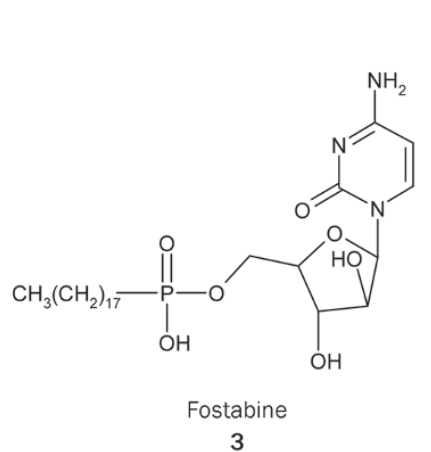

3

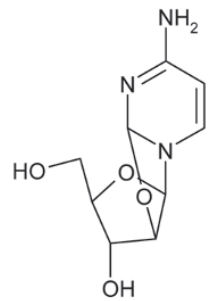

Ancitabine

2

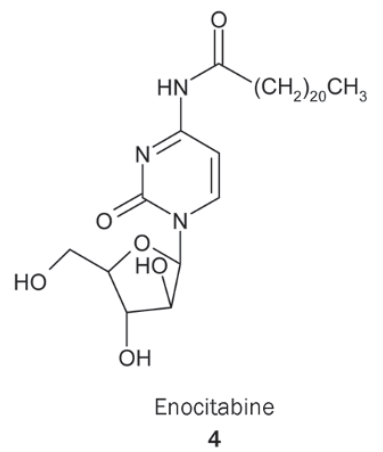

4
Figure 1. Cytarabine and its derivatives.<smiles>CC(C)C(N)C(=O)Nc1ccn(C2OC(CO)C(O)C2O)c(=O)n1</smiles>

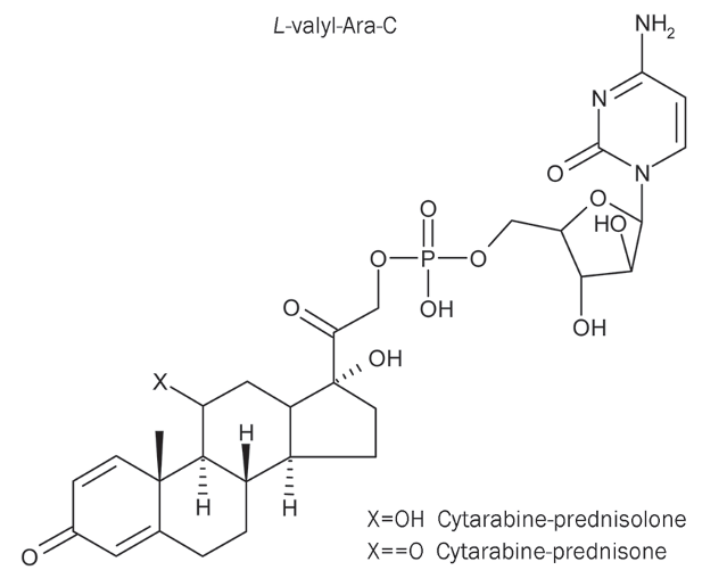

Figure 2. Conjugates of cytarabine with other moleculars. of cytarabine because the activation of cytarabine to triphosphate occurs at this position; thus, if the 5'-hydroxyl group is blocked by conjugation, it would prevent its phosphorylation until free cytarabine is liberated, which would result in changed pharmacokinetic parameters. The attachment of a lipidic structure to cytarabine is usually achieved through the remains of phosphates as in Ara-CDP (arabinosylcytosine diphosphate), which is a normal cytarabine metabolite preceding activation to its active metabolite Ara-CTP. Steroid-cytarabine conjugates are small molecular conjugates that deserved attention. For example, conjugating cytarabine with prednisolone or prednisone by forming a phosphodiester bond at the $5^{\prime}$ position has produced increased activities in L1210 leukemia models $^{[12]}$.

Individual bile acids are endogenous markers of liver transport and synthesis function. The enterohepatic circulation of bile acid makes it an attractive tool in designing pharmacological hybrid molecules and prodrugs with the view of improving intestinal absorption, increasing the metabolic stability of pharmaceuticals, specifically targeting drugs to organs involved in enterohepatic circulation, and sustaining therapeutically reasonable systemic concentrations of active agents ${ }^{[13-19]}$. In light of these characteristics of bile acids, cholic acid was chosen to modify cytarabine to improve its in vivo function and to achieve improved liver-targeting, which would make it possible to use cytarabine for treating liver cancer.

Herein, the synthesis of several cholic acid-cytarabine conjugates is described with different linkers. In vitro stability, portacaval samples and in vivo distribution were tested to investigate the metabolic process. Furthermore, the antitumor activities of the conjugates were also tested.

\section{Materials and methods}

Chemistry

Conjugate 6 consisted of cholic acid linked to cytarabine with a direct amide bond from cholic acid to cytarabine via ethyl chloroformate ${ }^{[20]}$. Cholic acid was linked to cytarabine with a direct ester bond in conjugate 7 and was synthesized via general conditions using dicyclohexylcarbodiimide and 4-dimethylaminopyridine (Scheme 1).

Conjugates $\mathbf{1 2}$ and $\mathbf{1 6}$ were designed to have a $\beta$-Alanine as the linker between cholic acid and cytarabine. The N-terminal of $\beta$-Alanine was attached to cholic acid with an amide bond, whereas the carboxyl group was linked to cytarabine via an ester bond or an amide bond to form 12 and 16, respectively. As shown in Scheme 2, commercially available $\beta$-Alanine was directly converted to an ester by thionyl chloride and EtOH. The resulting ester was coupled to cholic acid through isobutyl chloroformate to yield 10. After the hydrolysis of $\mathbf{1 0}$ by $\mathrm{NaOH}$, compound $\mathbf{1 2}$ was then synthesized in similar manner as 7 using the corresponding acid, 11. Cytarabine was first coupled to a Boc-protected $\beta$-Alanine to obtain 14. After deprotection by $\mathrm{HCl}$ in $\mathrm{EtOH}$, the resulting compound, 15, was reacted with cholic acid to produce $\mathbf{1 6}$.

The formation of the amide and ester bonds was determined by ${ }^{1} \mathrm{H}-\mathrm{NMR}$. The chemical shift, $\delta$, of hydrogen on 


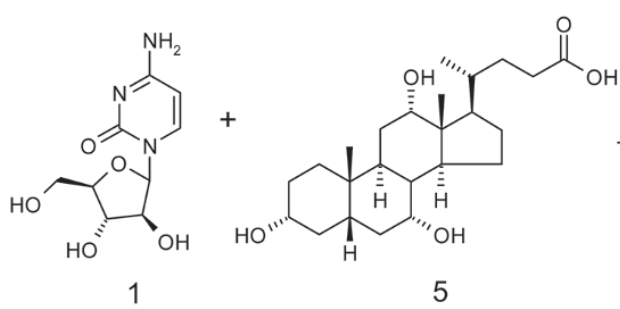<smiles>C[C@H](CCC(N)=O)[C@H]1CC[C@H]2[C@H]3[C@H]([C@H](O)C[C@@H]21)[C@@]1(C)CC[C@H](O)C[C@@H]1C[C@H]3O</smiles>

6<smiles></smiles>

$\mathrm{OH}$

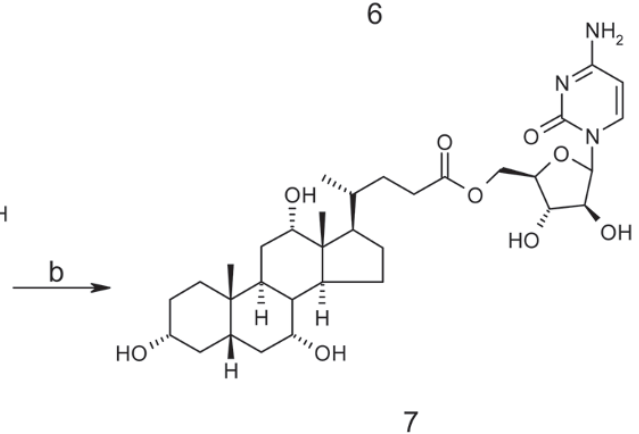

7

cheme 1. Reagents and conditions: (a) ethyl chloroformate, triethylamine, $\mathrm{N}, \mathrm{N}$-dimethylformamide, $-15^{\circ} \mathrm{C}$ to RT; (b) dicyclohexylcarbodiimide, 4dimethylaminopyridine, $\mathrm{N}, \mathrm{N}$-dimethylformamide.

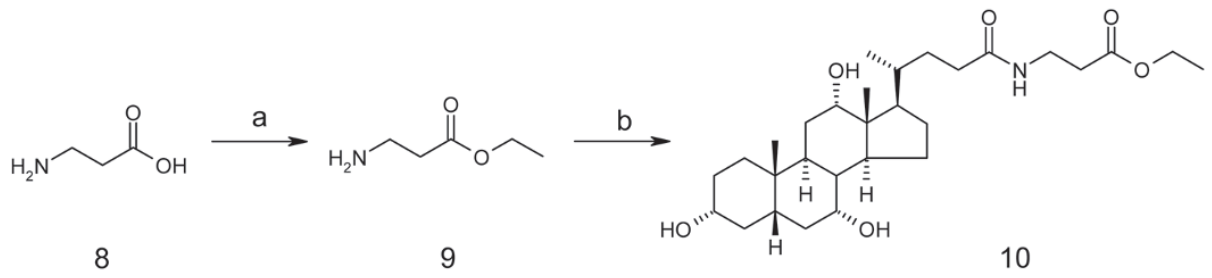

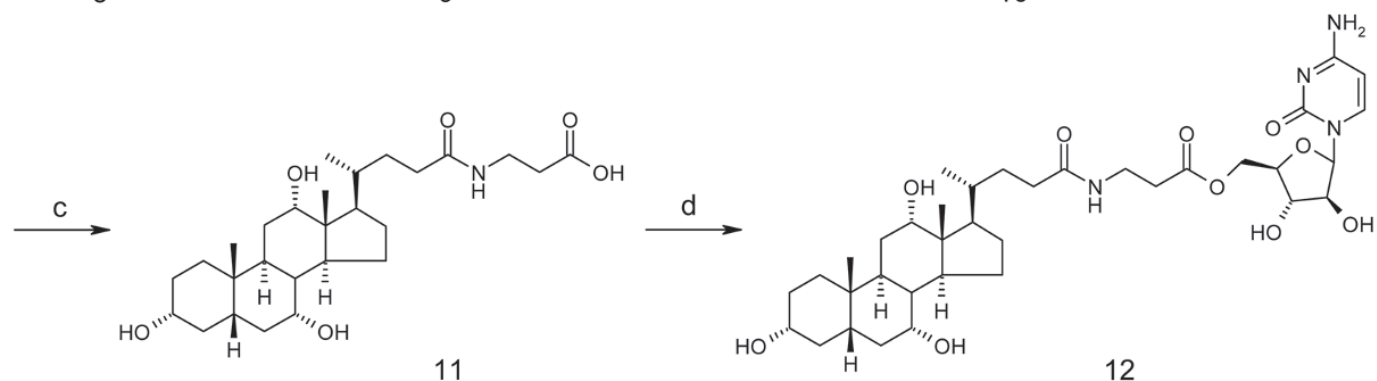<smiles>CC(C)(C)OC(=O)NCCC(=O)Nc1ccn(C2OC(CO)[C@@H](O)C2O)c(=O)n1</smiles>

1

13

14<smiles></smiles>

15

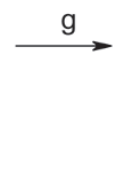

$\mathrm{HO}$

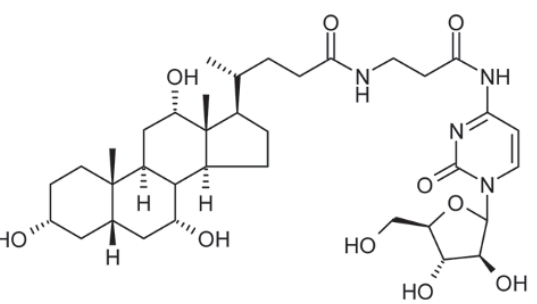

16
Scheme 2. Reagents and conditions: (a) thionyl chloride, $\mathrm{EtOH}$; (b) 5, isobutyl chloroformate, triethylamine, $\mathrm{N}, \mathrm{N}$ dimethylformamide, $-15{ }^{\circ} \mathrm{C}$ to RT; (c) $10 \% \mathrm{NaOH}$, EtOH; (d) 1, dicyclohexylcarbodiimide, 4-dimethylaminopyridine, $\mathrm{N}, \mathrm{N}$ dimethylformamide; (e) ethyl chloroformate, triethylamine, $\mathrm{N}, \mathrm{N}$-dimethylformamide, $-15{ }^{\circ} \mathrm{C}$ to $\mathrm{RT}$; (f) $\mathrm{HCl}$ in $\mathrm{EtOH}$; (g) 5, ethyl chloroformate, triethylamine, $\mathrm{N}, \mathrm{N}$-dimethylformamide, $-15{ }^{\circ} \mathrm{C}$ to RT. 
the 5-, 6-, and 5'-carbon of cytarabine was 6.0, 7.78, and 3.85, respectively. When $\mathrm{N}^{4}$ was coupled with the carboxyl group of cholic acid (compounds 6 and 7), $\delta$ of 5- and 6-hydrogen moved to 7.4 and 8.2, respectively; when the $5^{\prime}-\mathrm{OH}$ was coupled with the carboxyl group of cholic acid, $\delta$ of $5^{\prime}-\mathrm{H}$ shifted to 4.2 (Figure 3). Similar changes were observed in compounds 12 and 14.

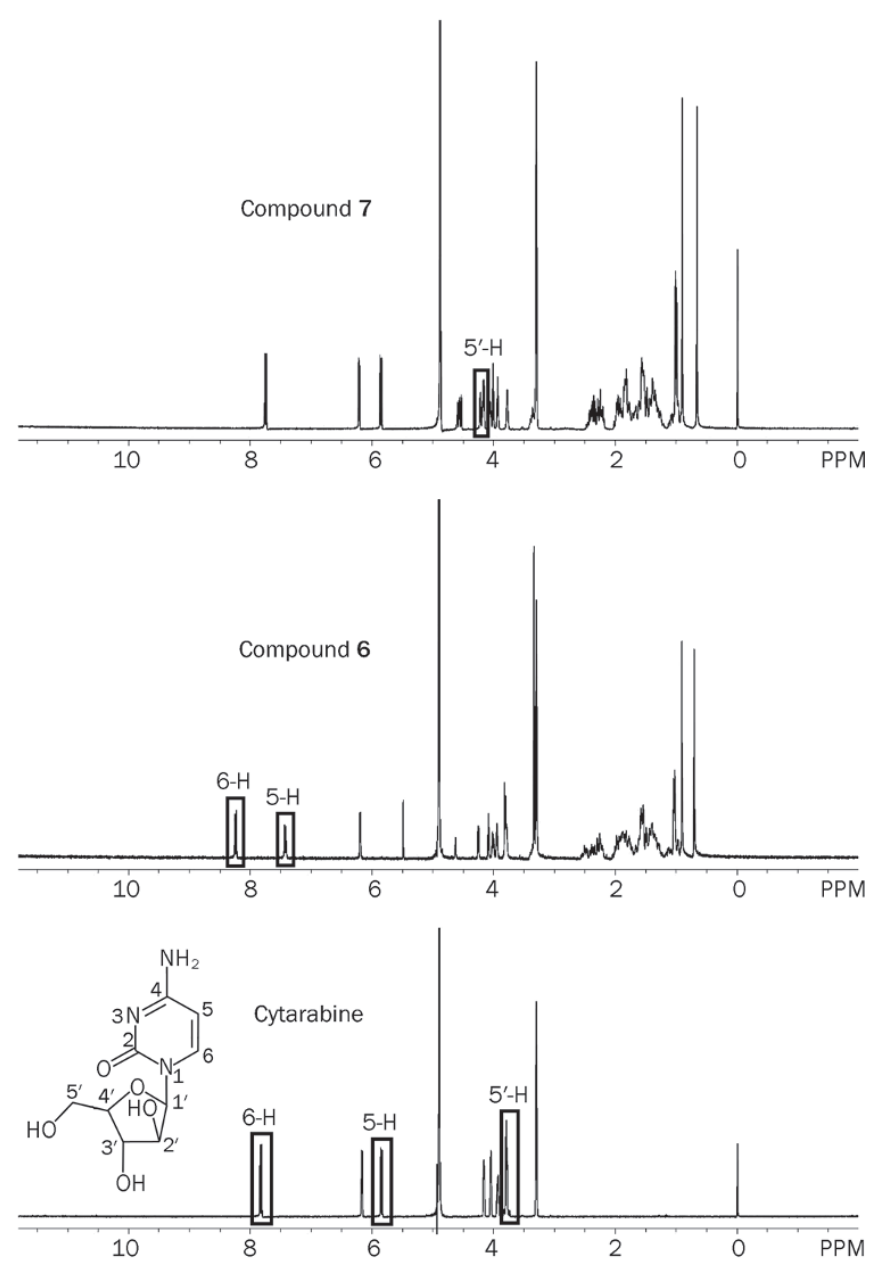

Figure 3. ${ }^{1} \mathrm{H}-\mathrm{NMR}$ spectrum of cytarabine, compound 6 and 7.

\section{In vitro stability}

Taking into account the possibility of the oral administration of the conjugates, the stability of all the newly synthesized compounds was tested in simulated gastric and intestinal fluids, mouse blood and liver homogenate. After incubation with the four matrixes, samples at different time points were subjected to HPLC to determine the extent of metabolism.

Simulated gastric and intestinal fluids were prepared according to the Chinese Pharmacopoeia. Mouse blood was collected, and heparin was added; the solution was then incubated at $37{ }^{\circ} \mathrm{C}$. Mouse liver homogenate was prepared using a buffer containing $50 \mathrm{mmol} / \mathrm{L}$ HEPES (pH 7.4), $150 \mathrm{mmol} / \mathrm{L}$ $\mathrm{NaCl}, 10 \%$ glycerol, $1 \%$ Tween $20,1.5 \mathrm{mmol} / \mathrm{L} \mathrm{MgCl}_{2}, 10$ $\mathrm{mmol} / \mathrm{L} \mathrm{Na}_{3} \mathrm{PO}_{4}, 100 \mathrm{mmol} / \mathrm{L} \mathrm{NaF}$, and $2 \mathrm{mmol} / \mathrm{L} \mathrm{Na}_{3} \mathrm{VO}_{4}{ }^{[21]}$.
Cytarabine, 6, 7, 12, and 16 were weighed (2 $\mathrm{mg}$ each), dissolved in $50 \mu \mathrm{L}$ DMSO and added to an $800 \mu \mathrm{L}$ matrix solution described above. The mixtures were incubated at $37{ }^{\circ} \mathrm{C}$, and the samples were obtained at different time points (gastric and intestinal fluid: $0,2,5$, and $24 \mathrm{~h}$; blood and liver homogenate: $0,1,3,5$, and $24 \mathrm{~h}$ ). All target compounds were analyzed using an HPLC system (HP1100) with UV-detection at $214 \mathrm{~nm}$. The separation was performed using a ZORBAX SB-C $\mathrm{C}_{18}(5 \mu \mathrm{m}$, $4.6 \mathrm{~mm} \times 150 \mathrm{~mm}$ ) with a $5 \mathrm{mmol} / \mathrm{L} \mathrm{ammonium} \mathrm{acetate} \mathrm{solu-}$ tion/methanol gradient at a flow rate of $1.0 \mathrm{~mL} / \mathrm{min}$ (column temperature was set to $35^{\circ} \mathrm{C}$ ).

\section{Portacaval sampling}

It has been reported that cytarabine deaminates rapidly in the liver ${ }^{[4]}$. To determine the forms of the conjugates after intestinal absorption and before reaching liver, portacaval blood samples were investigated by LC/MS after oral administration.

Four male Sprague-Dawley rats, weighing 200 to $230 \mathrm{~g}$, were orally administered conjugates $6,7,12$, and 16 separately (each compound was equivalent to $50 \mathrm{mg} / \mathrm{kg}$ cytarabine). The compounds administered were prepared by dissolving the compounds in propanediol and diluting them with the same volume of $0.5 \%$ carboxyl methyl cellulose (CMC) to 35 $\mathrm{mmol} / \mathrm{L}$. The rats were anaesthetized by barbital and the abdominal cavity was opened. The portavacal vein was intubated and blood samples were collected at $0.25,0.5$, and $1 \mathrm{~h}$. All of the samples were examined by LC-MS/MS. The analysis was performed using a LCQ Deca XP ion trap mass spectrometer (ThermoFinnigan, San Jose, CA, USA), an Atlantis analytical HILIC Silica column $(2.1 \mathrm{~mm} \times 100 \mathrm{~mm}, 5 \mu \mathrm{m})$ from Waters (made in Ireland); a mixture of methanol, $5 \mathrm{mmol} / \mathrm{L}$ ammonium acetate solution, water and acetonitrile containing $0.1 \%$ acetic acid was used as the mobile phase [Mobile phase $\mathrm{A}$ and $\mathrm{B}$ consisted of methanol and $5 \mathrm{mmol} / \mathrm{L}$ ammomium acetate; Mobile phases $C$ and D consisted of water and acetonitrile containing $0.1 \%$ acetic acid, respectively. Gradient chromatographic separation using mobile phases A, B, C, and D was as follows: $0 \mathrm{~min}(2 \% \mathrm{~A}, 5 \% \mathrm{~B}$, and 93\% D), $2.1 \mathrm{~min}(2 \%$ A, 5\% B, and 93\% D) , $2.5 \mathrm{~min}(2 \% \mathrm{~A}, 5 \% \mathrm{~B}, 60 \% \mathrm{D}$, and $33 \%$ C), $3.0 \mathrm{~min}(2 \% \mathrm{~A}, 5 \% \mathrm{~B}, 60 \% \mathrm{D}$, and $33 \% \mathrm{C}), 3.5 \mathrm{~min}(2 \% \mathrm{~A}, 5 \%$ $\mathrm{B}$, and $93 \% \mathrm{D})$ and finished at $6.5 \mathrm{~min}$ at a constant flow rate of $0.3 \mathrm{~mL} / \mathrm{min}]$. The MS/MS reactions selected to monitor cytarabine and Acyclovir (internal standard) were the transitions from $m / z 244 \rightarrow m / z 112$ and $m / z 226 \rightarrow m / z 152$ with collision energies of $32 \%$ and $30 \%$ of the instrumental maximum for $\mathrm{MS}^{2}$ experiments, respectively.

\section{In vivo distribution}

Male Kunming mice, weighing 18 to 20 g, were administered cytarabine $(50 \mathrm{mg} / \mathrm{kg})$, compound 6 or 16 orally, which was equivalent to $50 \mathrm{mg} / \mathrm{kg}$ cytarabine. Blood and liver samples were collected at different time points. All of the samples were examined by LC/MS.

The liver target index was calculated by the following formula: 


$$
\text { Liver target index }(\mathrm{LTI})=\frac{\mathrm{AUC}_{0-\mathrm{t}} \text { in liver }}{\mathrm{AUC}_{0-\mathrm{t}} \text { in plasma }}
$$

Normal, non-fasted male Kuming mice were administered ig with a dose of $50 \mathrm{mg} / \mathrm{kg}$ of cytarabine, $130 \mathrm{mg} / \mathrm{kg}$ of 6 and $145 \mathrm{mg} / \mathrm{kg}$ of 16, respectively. At specific times after administration, mice were anesthetized, and blood was drawn. The liver was removed, rapidly frozen on crushed ice and then stored at $-20^{\circ} \mathrm{C}$. The livers were slit, added to methanol with THU (final concentration of $0.4 \mathrm{mmol} / \mathrm{L}$ ) and homogenized. The centrifugation was carried out at 3500 revolutions per minute and $4{ }^{\circ} \mathrm{C}$ for $5 \mathrm{~min}$. A $100 \mu \mathrm{L}$ aliquot of supernatant was added to $25 \mu \mathrm{L}$ of the internal standard (Acyclovir) and $100 \mu \mathrm{L}$ of acetonitrile and mixed by vortexing for $1 \mathrm{~min}$. After centrifugation, the supernatant was transferred to a glass tube and evaporated until dry using an evaporator at $40{ }^{\circ} \mathrm{C}$ under a stream of nitrogen. The dried extract was then reconstituted in $100 \mu \mathrm{L}$ of the mobile phase and a $20 \mu \mathrm{L}$ aliquot was injected into the LC-MS/MS system for quantitative analysis.

Blood was added to THU (final concentration of 0.1 $\mathrm{mmol} / \mathrm{L}$ ) and chilled on crushed ice. The plasma was then separated by centrifugation (11000 revolutions per minute, $4{ }^{\circ} \mathrm{C}$ ), frozen and stored at $-20^{\circ} \mathrm{C}$. The mouse plasma samples were prepared using the protein precipitation technique. A $100 \mu \mathrm{L}$ aliquot of an acetonitrile solution containing $25 \mu \mathrm{L}$ of internal standard $(2 \mu \mathrm{g} / \mathrm{mL}$, Acyclovir) was added to $25 \mu \mathrm{L}$ of plasma, and mixed by vortexing for $1 \mathrm{~min}$. After centrifugation, the supernatant was transferred to a glass tube and evaporated at $40{ }^{\circ} \mathrm{C}$ under a stream of nitrogen. The dried extract was then reconstituted in $100 \mu \mathrm{L}$ of mobile phase, and a 20 $\mu \mathrm{L}$ aliquot was injected into the proposed LC-MS/MS system for quantitative analysis. The analysis was performed using a triple quadrupole mass spectrometer, TSQ Quantum Ultra (ThermoFinnigan, San Jose, CA, USA), equipped with an ESI source. Cytarabine and internal standard (IS) were analyzed by a Waters HILIC column $(150 \mathrm{~mm} \times 2.1 \mathrm{~mm}$ id, $5 \mu \mathrm{m})$ and protected by a SecurityGuard $\mathrm{C}_{18}$ guard column $(4 \mathrm{~mm} \times 3.0$ $\mathrm{mm}$ id). A mixture of acetonitrile- $10 \mathrm{mmol} / \mathrm{L}$ ammonium acetate-formic acid $(90: 10: 0.1, v / v / v)$ was used as the mobile phase at a flow rate of $0.70 \mathrm{~mL} / \mathrm{min}$. The retention time of cytarabine was approximately $6.6 \mathrm{~min}$. Compounds 6, 16, and IS were analyzed by a Venusil ASB- $\mathrm{C}_{18}$ column $(150 \mathrm{~mm} \times 4.6$ $\mathrm{mm}$ id, $5 \mu \mathrm{m}$ ) and protected by a SecurityGuard $\mathrm{C}_{18}$ guard column $(4 \mathrm{~mm} \times 3.0 \mathrm{~mm}$ id). A mixture of acetonitrile- $10 \mathrm{mmol} / \mathrm{L}$ ammonium acetate-formic acid (70:30:0.1, v/v/v) was used as the mobile phase at a flow-rate of $0.60 \mathrm{~mL} / \mathrm{min}$. The retention time of $\mathbf{6}$ and $\mathbf{1 6}$ was approximately $4 \mathrm{~min}$. The quantification was performed using the selective reaction monitoring (SRM) mode to study parent $\rightarrow$ product ion $(\mathrm{m} / \mathrm{z})$ transitions for cytarabine ( $244 \rightarrow 112$ and 212), 6 (634 $\rightarrow 112,337$, and 502), 16 $(705 \rightarrow 426$ and 573$)$ and IS (227 $\rightarrow 163)$, respectively.

\section{Antitumor activity}

Compounds were tested for their cytotoxic effects against a leukemia HL60 cell line by methyl-thiazol-tetrozolium (MTT) assays $^{[22]}$. Cells were treated with different concentrations of compounds for $72 \mathrm{~h}$. At the end of the treatment, $20 \mu \mathrm{L}$ of MTT $(5 \mathrm{mg} / \mathrm{mL})$ was added to each well and the plates were incubated at $37^{\circ} \mathrm{C}$ for $4 \mathrm{~h}$. Then "triplex solution" (10\% SDS$5 \%$ isobutanol- $\mathrm{HCl} 12 \mathrm{mmol} / \mathrm{L}$ ) was added, and the plates were incubated at $37^{\circ} \mathrm{C}$ for $12-20 \mathrm{~h}$. The $O D$ value was read on a plate reader at $570 \mathrm{~nm}$. The inhibition rate was calculated by the following equation: inhibition rate of proliferation $(\%)=\left(O D_{\text {control }}-O D_{\text {experiment }}\right) / O D_{\text {control }} \times 100 \%$.

\section{Results and discussion}

The in vitro stability test showed that all of the cholic acidcytarabine conjugates might release cytarabine when incubated with the four matrixes (Table 1). According to the results, gradual degradations of $\mathbf{6}$ and 16, which contain amide bonds, were found in acid gastric fluid $\left(t_{1 / 2}<8 \mathrm{~h}\right)$; released cytarabine was detected in the sample of conjugate 12 in mouse blood and liver homogenate $\left(t_{1 / 2}>8 \mathrm{~h}\right)$. Conjugate 7 , which had cytarabine directly linking to cholic acid via an ester bond, was completely converted into cytarabine in mouse blood within one hour.

The conjugated forms of $\mathbf{6}, \mathbf{1 2}$, and $\mathbf{1 6}$ were observed in portacaval samples, among which $\mathbf{1 6}$ had the most obvious MS characteristic peak. A small amount of cytarabine was detected at one hour only after the administration of conjugate 12. Neither the conjugate nor released cytarabine was observed when conjugate 7 was administered. The results showed that either conjugate 7 was not absorbed by the intestine or was metabolized to an unknown form (Figure 4).

Table 2 showed in vivo pharmacokinetics results of cytarabine, $\mathbf{6}$, and $\mathbf{1 6}$. The concentration of the compounds in the plasma, after the administration of cytarabine, reached their peaks at $0.5 \mathrm{~h}$, and only trace amounts were left in the blood after $4 \mathrm{~h}$. The $C_{\max }$ was $1.14 \mu \mathrm{g} / \mathrm{mL}$. The $C_{\max }, T_{\max }$ and $\mathrm{Auc}_{0-\mathrm{t}}$ of the livers were all lower than those of the plasma; additionally, the elimination rate in liver was found to be much faster (Figure 5A). The released cytarabine of conjugate $\mathbf{6}$ was observed in the plasma samples but not in the liver. The $C_{\max }$ of the conjugate in the plasma and liver were 0.091 and 3.25 $\mu \mathrm{g} / \mathrm{mL}$ respectively, and $0.188 \mu \mathrm{g} / \mathrm{mL}$ for released cytarabine in plasma (Figure 5B). Conjugate $\mathbf{1 6}$ also released cytarabine in vivo. The $C_{\max }$ of the conjugate in plasma and liver were 0.826 and $14.868 \mu \mathrm{g} / \mathrm{mL}$, whereas released cytarabine levels in plasma and liver were 0.097 and $0.455 \mu \mathrm{g} / \mathrm{mL}$ (Figure 5C), respectively. Although 12 was present in the portacaval samples, only a small amount of the conjugate form could be detected in the liver, and it was not found in plasma. Released cytarabine was not detected in the liver or plasma. Thus, data on conjugate $\mathbf{1 2}$ were not provided. According to the calculation of $\mathrm{AUC}_{0-\mathrm{t}}$, the liver targeting index was 0.17 for cytarabine, 34.9 for $\mathbf{6}$, and 16.3 for $\mathbf{1 6}$.

Both conjugates $\mathbf{6}$ and $\mathbf{1 6}$ showed good liver targeting compared to cytarabine. The LTI of 6 reached 34.9, which was 200 times more than cytarabine. The LTI of $\mathbf{1 6}$ also reached 16.3, and the $C_{\max }$ was $14.868 \mu \mathrm{g} / \mathrm{mL}$, which demonstrated good absorption. The stability of the amide bond prevented the conjugates from degradation through oral absorption, 
Table 1. Results of the in vitro stability test.

\begin{tabular}{|c|c|c|c|c|c|c|c|c|c|c|c|c|c|c|c|c|c|c|c|}
\hline & & & & & & & & & & Condi & itions & & & & & & & & \\
\hline Tes & ted & & imulated & d gastric & fluid & Simb & Ilated & ntestir & nal fluid & & & Mouse b & lood & & & Mouse & e liver hc & omogenat & \\
\hline & & $\mathrm{Oh}$ & $2 \mathrm{~h}$ & $5 \mathrm{~h}$ & $24 \mathrm{~h}$ & $\mathrm{Oh}$ & $2 \mathrm{~h}$ & $5 \mathrm{~h}$ & $24 \mathrm{~h}$ & $\mathrm{Oh}$ & $1 \mathrm{~h}$ & $3 \mathrm{~h}$ & $5 \mathrm{~h}$ & $24 \mathrm{~h}$ & $\mathrm{Oh}$ & $1 \mathrm{~h}$ & $3 \mathrm{~h}$ & $5 \mathrm{~h}$ & $24 \mathrm{~h}$ \\
\hline Ara- & & 100 & 100 & 100 & 100 & 100 & 100 & 100 & 100 & 100 & 100 & 100 & 100 & 100 & 100 & 100 & 100 & 100 & 66.89 \\
\hline 6 & 6 & 100 & 84.51 & 50.71 & 34.30 & 100 & 100 & 100 & 100 & 100 & 100 & 100 & 100 & 100 & 100 & 95.15 & 91.74 & 91.40 & 87.88 \\
\hline & Ara-C & 0 & 15.49 & 49.29 & 65.70 & 0 & 0 & 0 & 0 & 0 & 0 & 0 & 0 & 0 & 0 & 4.85 & 8.26 & 8.60 & 12.12 \\
\hline 7 & 7 & 100 & 100 & 100 & 78.14 & 100 & 100 & 100 & 100 & 100 & 0 & 0 & NT & NT & 100 & 100 & 100 & 100 & 100 \\
\hline & Ara-C & 0 & 0 & 0 & 21.86 & 0 & 0 & 0 & 0 & 0 & 100 & 100 & NT & NT & 0 & 0 & 0 & 0 & 0 \\
\hline 12 & 12 & 100 & 100 & 100 & 90.66 & 100 & 100 & 100 & 80.40 & 100 & 81.66 & 62.84 & 55.07 & 16.87 & 100 & 82.51 & NT & 78.83 & 72.25 \\
\hline & Ara-C & 0 & 0 & 0 & 9.34 & 0 & 0 & 0 & 19.60 & 0 & 18.34 & 37.16 & 44.93 & 83.13 & 0 & 17.49 & NT & 21.17 & 27.75 \\
\hline 16 & 16 & 100 & 78.48 & 56.12 & 21.34 & 100 & 100 & 100 & 100 & 100 & 100 & 100 & 100 & 100 & 100 & NT & 100 & 100 & 83.29 \\
\hline & Ara-C & 0 & 21.52 & 43.87 & 78.66 & 0 & 0 & 0 & 0 & 0 & 0 & 0 & 0 & 0 & 0 & NT & 0 & 0 & 16.71 \\
\hline
\end{tabular}

NT: not tested.

Table 2. Pharmacokinetic parameters of cytarabine, 6 and 16 after oral administration to Kunming mice.*

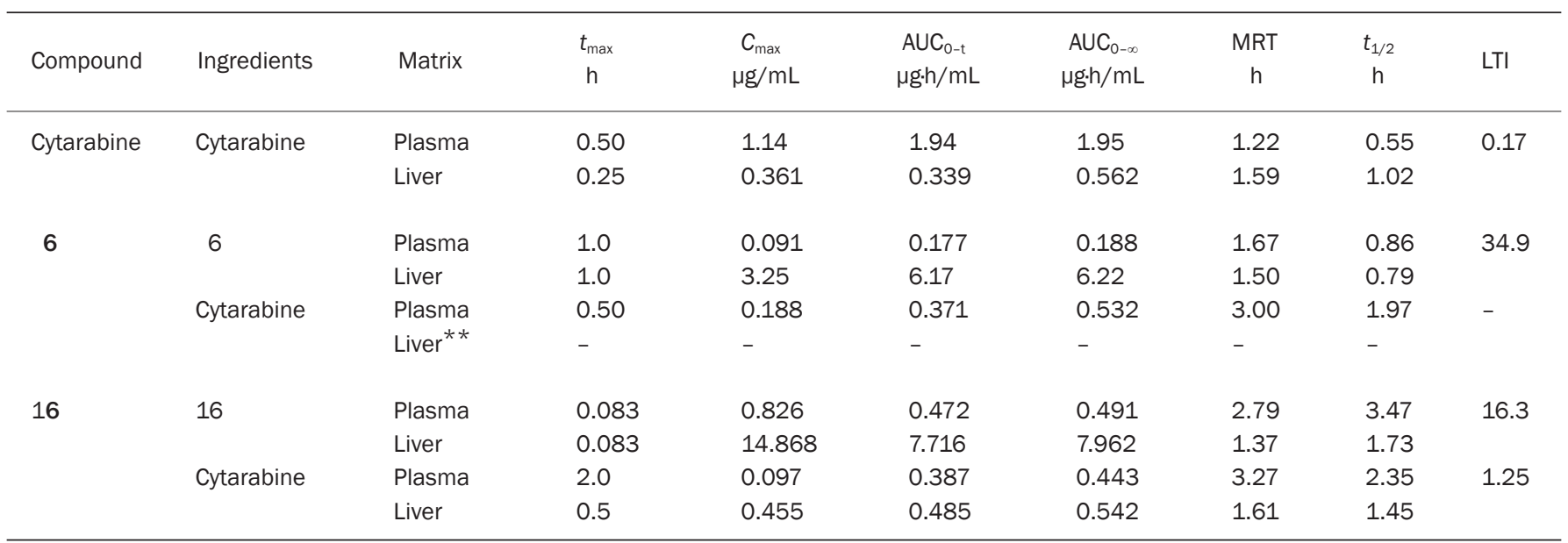

*: All the pharmacokinetic parameters were calculated using DAS 2.0.

$* *$ : Not detected.

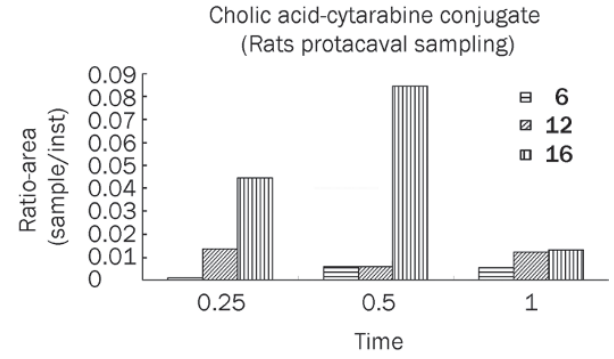

Figure 4. All the samples were detected by LC/MS. The ordinate represented the peak-area ratio of the conjugates to the internal standard (Acyclovir). whereas in vivo, the bond could be metabolized, which made it an appropriate link. The $C_{\max }$ of $\mathbf{1 6}$ was approximately 4 times larger than conjugate 6 , which showed that using $\beta$-Alanine as the linker might increase cytarabine's absorption.

The antitumor activities of conjugates 6, 16, and 12 were tested on HL60 cells (Table 3). All three compounds showed potent antitumor activities on cytarabine-sensitive HL60 cells, which indicated that conjugating cytarabine to cholic acid allowed its antitumor activities to be retained.

In conclusion, a new series of cholic acid-cytarabine conjugates with antitumor activities have been described. Some of them exhibited excellent targeting of the liver and good absorption compared to cytarabine alone. Further studies will 

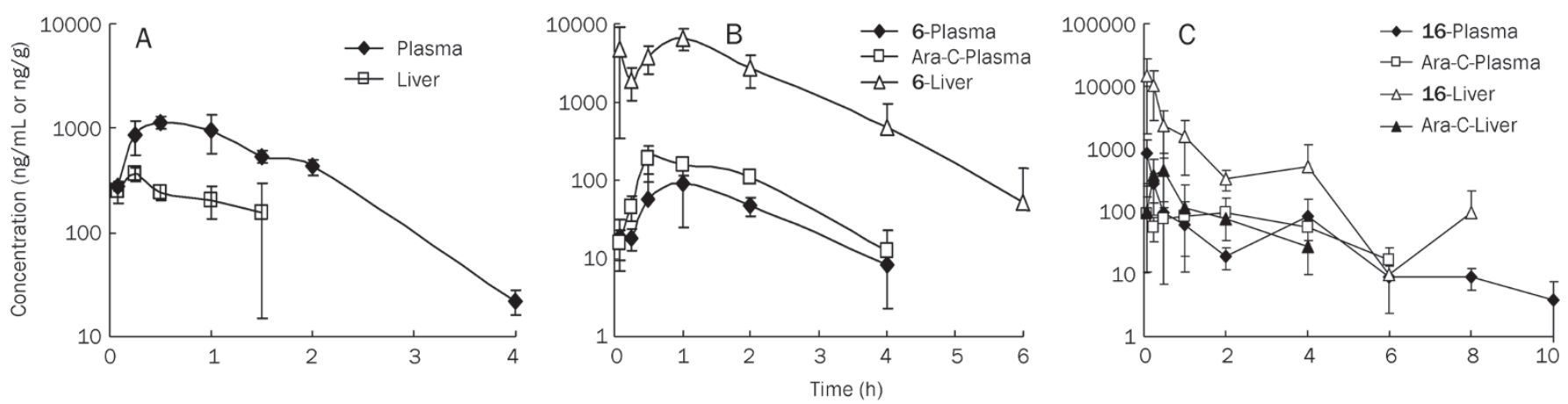

Figure 5. A) Plasma and liver concentrations following oral administration of Ara-C (50 mg/kg). B) Plasma and liver concentrations following oral administration of $6(130 \mathrm{mg} / \mathrm{kg})$. C) Plasma and liver concentrations following oral administration of 16 (145 mg/kg). Mean \pm SD. $n=3$.

Table 3. Antitumor activities on HL60 cells after 72 h. Mean \pm SD. $n=3$.

\begin{tabular}{cc}
\hline Compounds & $\mathrm{IC}_{50}(\mu \mathrm{mol} / \mathrm{L})$ \\
\hline Cytarabine & $0.19 \pm 0.13$ \\
6 & $2.09 \pm 1.23$ \\
12 & $0.99 \pm 0.65$ \\
16 & $2.96 \pm 2.03$ \\
\hline
\end{tabular}

continue by developing more conjugates with different linkers. Biological evaluations will be conducted on conjugates 6 and $\mathbf{1 6}$ in the near future.

\section{Experimental}

The reagents were purchased from Alfa-Aesar (Karlsruhe, Germany), Acros (Geel, Belgium) and Shanghai Chemical Reagent Company (Shanghai, China) and were used without further purification. Analytical thin-layer chromatography was performed on HSGF 254 (150-200 $\mu \mathrm{m}$ thickness; Yantai Huiyou Company, Yantai, Shandong, China). The IR spectra were recorded on a Nicolet Magna 750 FTIR spectrometer, and the ${ }^{1} \mathrm{H}$ NMR (300 MHz or $400 \mathrm{MHz}$ ) spectra were recorded on a Varian Mercury-300 or a 400 High Performance Digital FTNMR using tetramethylsilane as an internal standard. The ${ }^{13} \mathrm{C}$ NMR (100 MHz) spectra were determined using a Varian Mercury-400 High Performance Digital FT-NMR. HPLC analysis was performed using a Gilson HPLC system with UV detection at 214 and $254 \mathrm{~nm}$. UV scanning was performed on an Agilent HP1100. LC-MS spectra were obtained using a LCQ Deca XP ion trap mass spectrometer (ThermoFinnigan, San Jose, CA, USA). Accurate mass measurements were carried out on a Q-TOF ultima Globe mass spectrometer (Micromass, Manchester, UK).

(4R)-N-(1-((3S,4S,5R)-3,4-dihydroxy-5-(hydroxymethyl)tetrahydrofuran-2-yl)-2-oxo-1,2-dihydropyrimidin-4-yl)-4-((3R,5S,7R,12S, 13R,14S,17R)-3,7,12-trihydroxy-10,13-dimethylhexadecahydro1H-cyclopenta[a]phenanthren-17-yl)pentanamide (6)

Cholic acid (1.16 g, $3 \mathrm{mmol}$ ) and triethylamine (TEA, 0.39 $\mathrm{mL}, 3 \mathrm{mmol}$ ) were dissolved in dry $N, N$-dimethylformamide
(DMF, $20 \mathrm{~mL}$ ). The mixture was cooled to $-15{ }^{\circ} \mathrm{C}$, and ethyl chloroformate $(0.31 \mathrm{~mL}, 3 \mathrm{mmol})$ was then added. After being stirred for $20 \mathrm{~min}$, cytarabine $(0.69 \mathrm{mg}, 3 \mathrm{mmol})$ in $15 \mathrm{~mL}$ DMF was added the mixture, dropwise. The reaction mixture was stirred at $-15^{\circ} \mathrm{C}$ for $1 \mathrm{~h}$ and at RT overnight. The mixture was filtered, and the filtrate was concentrated. The residue was subjected to silica gel chromatography (dichloromethane/ methanol, $10: 1$ to $4: 1$ ) to yield 6 as a white solid (1.34 g, 75\%).

mp 190-192 ${ }^{\circ} \mathrm{C}$.

IR $\left(\mathrm{KBr} \mathrm{cm}{ }^{-1}\right): 3396,2933,2868,1711,1649,1566,1493,1389$, 1315, 1117, 1076, 1047, 980, 951, 804, 609, 559.

${ }^{1} \mathrm{H}-\mathrm{NMR}\left(\mathrm{CD}_{3} \mathrm{OD}, 300 \mathrm{MHz}\right): \delta 8.22(\mathrm{~d}, 1 \mathrm{H}, \mathrm{J}=7.6 \mathrm{~Hz}), 7.4(\mathrm{~d}$, $1 \mathrm{H}, \mathrm{J}=7.1 \mathrm{~Hz}), 6.2(\mathrm{~d}, 1 \mathrm{H}, \mathrm{J}=3.8 \mathrm{~Hz}), 4.25(\mathrm{~m}, 1 \mathrm{H}), 4.08(\mathrm{t}, 1 \mathrm{H})$, $4.01(\mathrm{~m}, 1 \mathrm{H}), 3.94(\mathrm{~s}, 1 \mathrm{H}), 3.8(\mathrm{~m}, 3 \mathrm{H}), 2.6-1.05(\mathrm{~m}, 25 \mathrm{H}), 1.02$ $(\mathrm{d}, 3 \mathrm{H}, \mathrm{J}=6.2 \mathrm{~Hz}), 0.9(\mathrm{~s}, 3 \mathrm{H}), 0.7(\mathrm{~s}, 3 \mathrm{H})$.

${ }^{13} \mathrm{C}$ NMR (100 MHz, d ${ }^{6}$-DMSO) $\delta 174.5,162.3,154.7,146.7$, 94.5, 87.1, 85.3, 76.2, 74.7, 71.1, 70.6, 66.4, 61.1, 46.3, 45.8, 41.6, $41.5,35.4,35.3,34.9,34.5,33.7,31.0,30.4,28.6,27.4,26.3,22.9$, $22.7,17.1,12.4$.

MS (ESI): $m / z 634(\mathrm{M}+\mathrm{H})^{+}$; HRMS calcd for $\mathrm{C}_{33} \mathrm{H}_{51} \mathrm{~N}_{3} \mathrm{O}_{9} \mathrm{Na}$ : $656.3523(\mathrm{M}+\mathrm{Na})^{+}$; Found: 656.3536.

(4R)-((2R,3S,4S)-5-(4-amino-2-oxopyrimidin-1(2H)-yl)-3,4-dihydroxytetrahydrofuran-2-yl)methyl-4-((3R,5S,7R,9S,10S,12S,13R, 14S,17R)-3,7,12-trihydroxy-10,13-dimethylhexadecahydro-1Hcyclopenta[a]phenanthren-17-yl)pentanoate (7)

Cytarabine (1.46 g, $6 \mathrm{mmol})$ was dissolved in dry DMF (30 $\mathrm{mL}$ ) and heated to $60{ }^{\circ} \mathrm{C}$. Cholic acid (3.67 g, $\left.9 \mathrm{mmol}\right)$, dicyclohexylcarbodiimide (DCC, $1.79 \mathrm{~g}, 9 \mathrm{mmol}$ ) and 4-dimethylaminopyridine (DMAP, $109 \mathrm{mg}, 0.9 \mathrm{mmol}$ ) were added. The mixture was cooled to RT and stirred for $2 \mathrm{~d}$. Then, a second addition of cholic acid $(3.67 \mathrm{~g}, 9 \mathrm{mmol}), \mathrm{DCC}(1.79 \mathrm{mg}$, $9 \mathrm{mmol}$ ) and DMAP (109 mg, $0.9 \mathrm{mmol})$ was made. The mixture was stirred continuously for $4 \mathrm{~d}$. The reaction mixture was filtered, and the filtrate was concentrated. The residue was subjected to silica gel chromatography (dichloromethane/ methanol, 15:1) to yield 7 as a white solid (310 mg, 10\%).

mp 204-205 ${ }^{\circ} \mathrm{C}$.

IR $\left(\mathrm{KBr} \mathrm{cm}^{-1}\right)$ : 3423, 2929, 2868, 1730, 1649, 1491, 1377, 1290, $1076,1045,795,735,609$.

${ }^{1} \mathrm{H}-\mathrm{NMR}\left(\mathrm{CD}_{3} \mathrm{OD}, 300 \mathrm{MHz}\right): \delta 7.76$ (d, 1H, J=7.8 Hz), 6.22 
(d, 1H, J=3.9 Hz), 5.86 (d, 1H, J=7.5 Hz), 4.57 (m, 1H), 4.20 (m, $2 \mathrm{H}), 4.07(\mathrm{~m}, 1 \mathrm{H}), 4.01(\mathrm{~m}, 1 \mathrm{H}), 3.94$ (brs, $1 \mathrm{H}), 3.78(\mathrm{~d}, 1 \mathrm{H}, \mathrm{J}=2.8$ $\mathrm{Hz}), 3.37$ (m, 1H), 2.50-2.15 (m, 4H), 2.05-1.10 (m, 20H), $1.0(\mathrm{~d}$, $3 \mathrm{H}, \mathrm{J}=6.5 \mathrm{~Hz}), 0.9$ (s, 3H), 0.65 (s, 3H).

${ }^{13} \mathrm{C}$ NMR $\left(100 \mathrm{MHz}, \mathrm{CD}_{3} \mathrm{OD}\right) \delta 176.2,168.0,158.6,145.3,95.3$, 89.2, 84.8, 78.9, 76.8, 74.5, 73.3, 69.5, 65.3, 48.6, 48.0, 43.7, 43.5, $41.4,41.0,37.0,36.4,32.8,32.6,31.7,30.1,29.2,28.4,24.7,23.7$, $18.0,13.4$.

MS (ESI): $m / z 634(\mathrm{M}+\mathrm{H})^{+}$; HRMS calcd for $\mathrm{C}_{33} \mathrm{H}_{51} \mathrm{~N}_{3} \mathrm{O}_{9} \mathrm{Na}$ : $656.3523(\mathrm{M}+\mathrm{Na})^{+}$; Found: 656.3531.

Ethyl 3-((4R)-4-((3R,5S,7R,9S,10S,12S,13R,14S,17R)-3,7,12-trihydroxy-10,13-dimethylhexadecahydro-1H-cyclopenta[a]phenanthren-17-yl)pentanamido)propanoate (10)

Thionyl chloride $(20 \mathrm{~mL})$ was added dropwise to anhydrous ethanol $(80 \mathrm{~mL})$, and the temperature did not exceed $25^{\circ} \mathrm{C}$. $\beta$-Alanine $(9 \mathrm{~g}, 0.1 \mathrm{~mol})$ was then added. After stirring at $50{ }^{\circ} \mathrm{C}$ for $3 \mathrm{~h}, \beta$-Alanine dissolved. The mixture was stirred at RT overnight. The solvent was evaporated and ether was added to the residue. A white solid was formed, filtered and then dried $\left(\mathrm{Na}_{2} \mathrm{SO}_{4}\right)$ to yield $16 \mathrm{~g} 9(100 \%)$. Cholic acid (5.57 g, 13.6 $\mathrm{mmol}$ ) and triethylamine (TEA, $1.92 \mathrm{~mL}, 15 \mathrm{mmol}$ ) were dissolved in dry DMF (45 mL). The mixture was cooled to $-15^{\circ} \mathrm{C}$, and isobutyl chloroformate $(1.78 \mathrm{~mL}, 17 \mathrm{mmol})$ was added. After stirring for $5 \mathrm{~min}, 9(2.3 \mathrm{~g}, 20 \mathrm{mmol})$ and TEA $(3.84 \mathrm{~mL}$, $30 \mathrm{mmol}$ ) were combined with $10 \mathrm{~mL} \mathrm{DMF}$, which was added dropwise. The reaction mixture was stirred at $-15^{\circ} \mathrm{C}$ for $1 \mathrm{~h}$ and at RT overnight. The mixture was filtered, and the filtration was concentrated. The residue was dissolved in ethyl acetate and washed with water 4 times (water/ethyl acetate, 1:2). The organic layer was combined and washed with 0.5 $\mathrm{mol} / \mathrm{L} \mathrm{NaOH}, 0.5 \mathrm{~mol} / \mathrm{L} \mathrm{HCl}$ and brine; it was then dried and concentrated to yield 10 as a white solid $5.67 \mathrm{~g}(87 \%)$.

${ }^{1} \mathrm{H}-\mathrm{NMR}\left(\mathrm{CD}_{3} \mathrm{OD}, 300 \mathrm{MHz}\right): \delta 4.12(\mathrm{~m}, 2 \mathrm{H}), 3.94$ (brs, $\left.1 \mathrm{H}\right)$, 3.78 (brs, $1 \mathrm{H}), 3.4(\mathrm{~m}, 3 \mathrm{H}), 2.5(\mathrm{t}, 2 \mathrm{H}, \mathrm{J}=6.6 \mathrm{~Hz}), 2.4-1.2(\mathrm{~m}$, $24 \mathrm{H}), 1.24(\mathrm{t}, 3 \mathrm{H}, \mathrm{J}=7.2 \mathrm{~Hz}), 1.0(\mathrm{~d}, 3 \mathrm{H}, \mathrm{J}=6.4 \mathrm{~Hz}), 0.9(\mathrm{~s}, 3 \mathrm{H})$, $0.7(\mathrm{~s}, 3 \mathrm{H})$.

MS (ESI): $m / z 1015(2 \mathrm{M}+\mathrm{H})^{+}$.

3-((4R)-4-((3R,5S, 7R,9S,10S,12S,13R,14S, 17R)-3, 7,12-trihydroxy-10,13-dimethylhexadecahydro-1H-cyclopenta[a]phenanthren-17-yl)pentanamido)propanoic acid (11)

Compound 10 (3.9 g, $7.7 \mathrm{mmol}$ ) was dissolved in ethanol (30 $\mathrm{mL})$ and added to a solution of $10 \% \mathrm{NaOH}(30 \mathrm{~mL})$. The reaction mixture was stirred at RT overnight and then poured into ice water and acidified with $1 \mathrm{~mol} / \mathrm{L} \mathrm{HCl}$, which was extracted with ethyl acetate 3 times. The organic layer was combined and washed with brine, dried $\left(\mathrm{Na}_{2} \mathrm{SO}_{4}\right)$ and concentrated to yield 11 as a white solid $3.2 \mathrm{~g}(87 \%)$.

${ }^{1} \mathrm{H}-\mathrm{NMR}\left(\mathrm{CD}_{3} \mathrm{OD}, 300 \mathrm{MHz}\right): \delta 3.95$ (brs, $\left.1 \mathrm{H}\right), 3.8$ (brs, $\left.1 \mathrm{H}\right)$, $3.4(\mathrm{t}, 3 \mathrm{H}, \mathrm{J}=7 \mathrm{~Hz}), 2.5(\mathrm{t}, 2 \mathrm{H}, \mathrm{J}=6.8 \mathrm{~Hz}), 2.4-1.05(\mathrm{~m}, 24 \mathrm{H}), 1.0$ $(\mathrm{d}, 3 \mathrm{H}, \mathrm{J}=6.1 \mathrm{~Hz}), 0.9(\mathrm{~s}, 3 \mathrm{H}), 0.7(\mathrm{~s}, 3 \mathrm{H})$.

MS (ESI): $m / z 959(2 \mathrm{M}+\mathrm{H})^{+}$.

((2R,3S,4S)-5-(4-amino-2-oxopyrimidin-1(2H)-yl)-3,4-dihydroxytetrahydrofuran-2-yl)methyl- 3-((4R)-4-((3R,5S,7R,9S,10S,12S,
13R,14S,17R)-3,7,12-trihydroxy-10,13-dimethylhexadecahydro1H-cyclopenta[a]phenanthren-17-yl)pentanamido)propanoate (12)

Cytarabine (324 mg, $1.33 \mathrm{mmol}$ ) was dissolved in dry DMF $(12 \mathrm{~mL})$ and heated to $60{ }^{\circ} \mathrm{C}$. Compound $11(0.96 \mathrm{~g}, 2 \mathrm{mmol})$, DCC (453 mg, $2.2 \mathrm{mmol}$ ) and DMAP (24.4 mg, $0.2 \mathrm{mmol}$ ) were then added. The mixture was cooled to RT and stirred for $2 \mathrm{~d}$. Another addition of $\mathbf{1 1}$ (0.96 g, $2 \mathrm{mmol})$, DCC (453 mg, $2.2 \mathrm{mmol}$ ) and DMAP (24.4 $\mathrm{mg}, 0.2 \mathrm{mmol})$ was made. The mixture continued to stir for $2 \mathrm{~d}$ and was then filtered. The filtration was concentrated, and the residue was subjected to silica gel chromatography (dichloromethane/methanol, 15:1) to yield 12 as a white solid $200 \mathrm{mg}(15 \%)$.

mp $174-176^{\circ} \mathrm{C}$.

${ }^{1} \mathrm{H}-\mathrm{NMR}\left(\mathrm{CD}_{3} \mathrm{OD}, 300 \mathrm{MHz}\right): \delta 7.72(\mathrm{~d}, 1 \mathrm{H}, \mathrm{J}=7.4 \mathrm{~Hz}), 6.20$ (d, 1H, J=3.5 Hz), 5.87 (d, 1H, J=7.6 Hz), 4.51 (m, 1H), 4.27 (m, $1 \mathrm{H}), 4.18(\mathrm{~m}, 1 \mathrm{H}), 4.08(\mathrm{~m}, 1 \mathrm{H}), 4.02(\mathrm{~m}, 1 \mathrm{H}), 3.93$ (brs, 1H), $3.78(\mathrm{~m}, 1 \mathrm{H}), 3.44(\mathrm{t}, 2 \mathrm{H}, \mathrm{J}=6.9 \mathrm{~Hz}), 2.58(\mathrm{t}, 2 \mathrm{H}, \mathrm{J}=6.3 \mathrm{~Hz}), 2.4-$ $1.1(\mathrm{~m}, 25 \mathrm{H}), 0.99(\mathrm{~d}, 3 \mathrm{H}, \mathrm{J}=6.4 \mathrm{~Hz}), 0.90(\mathrm{~s}, 3 \mathrm{H}), 0.69(\mathrm{~s}, 3 \mathrm{H})$.

${ }^{13} \mathrm{C}$ NMR $\left(100 \mathrm{MHz}, \mathrm{CD}_{3} \mathrm{OD}\right) \delta 177.5,173.6,168.0,158.6$, 145.0, 95.3, 89.2, 84.6, 79.0, 76.8, 74.5, 73.3, 69.5, 65.6, 55.3, 48.4, $47.9,43.6,43.4,41.5,40.9,37.3,36.9,36.8,36.4,36.3,35.4,34.5$, 33.7, 31.6, 30.0, 29.2, 28.3, 24.7, 23.7, 18.2, 13.5 .

MS (ESI): $m / z 705(\mathrm{M}+\mathrm{H})^{+}$; HRMS calcd for $\mathrm{C}_{36} \mathrm{H}_{56} \mathrm{~N}_{4} \mathrm{O}_{10} \mathrm{Na}$ : $727.3894(\mathrm{M}+\mathrm{Na})^{+}$; Found: 727.3913.

tert-butyl 3-(1-((3S,4S,5R)-3,4-dihydroxy-5-(hydroxymethyl)tetrahydrofuran-2-yl)-2-oxo-1,2-dihydropyrimidin-4-ylamino)-3-oxopropylcarbamate (14)

Boc- $\beta$-Ala-OH (945 mg, $5 \mathrm{mmol}$ ) and triethylamine $(0.6 \mathrm{~mL}, 5$ $\mathrm{mmol})$ were dissolved in dry DMF $(30 \mathrm{~mL})$. The mixture was cooled to $-15{ }^{\circ} \mathrm{C}$, and ethyl chloroformate $(0.48 \mathrm{~mL}, 5 \mathrm{mmol})$ was added. After stirring for $30 \mathrm{~min}$, cytarabine $(1.22 \mathrm{~g}, 5$ $\mathrm{mmol}$ ) in $10 \mathrm{~mL}$ DMF was added dropwise to the mixture. The reaction mixture was stirred at $-15{ }^{\circ} \mathrm{C}$ for $30 \mathrm{~min}$ and then at RT overnight. The reaction mixture was filtered, and the filtration was concentrated and subjected to silica gel chromatography (dichloromethane/methanol, 20:1) to yield 14 as a white solid $(1.7 \mathrm{~g}, 82 \%)$.

${ }^{1} \mathrm{H}-\mathrm{NMR}\left(\mathrm{CD}_{3} \mathrm{OD}, 300 \mathrm{MHz}\right): \delta 8.24$ (d, 1H, J=7.5 Hz), 7.42 $(\mathrm{d}, 1 \mathrm{H}, \mathrm{J}=7.5 \mathrm{~Hz}), 6.19(\mathrm{~d}, 1 \mathrm{H}, \mathrm{J}=3.9 \mathrm{~Hz}), 4.25(\mathrm{~m}, 1 \mathrm{H}), 4.08(\mathrm{t}$, $1 \mathrm{H}, \mathrm{J}=2.4 \mathrm{~Hz}), 4.01(\mathrm{~m}, 1 \mathrm{H}), 3.81(\mathrm{~d}, 2 \mathrm{H}, \mathrm{J}=4.8 \mathrm{~Hz}), 3.36(\mathrm{t}, 2 \mathrm{H}$, $\mathrm{J}=6.6 \mathrm{~Hz}), 2.62(\mathrm{t}, 2 \mathrm{H}, \mathrm{J}=6.3 \mathrm{~Hz}), 1.41(\mathrm{~s}, 9 \mathrm{H})$.

MS (ESI): $m / z 415(\mathrm{M}+\mathrm{H})^{+}$.

(4R)-N-(3-(1-((3S,4S,5R)-3,4-dihydroxy-5-(hydroxymethyl)tetrahydrofuran-2-yl)-2-oxo-1,2-dihydropyrimidin-4-ylamino)-3-oxopropyl)-4-((3R,5S,7R,9S,10S,12S,13R,14S,17R)-3,7,12-trihydroxy10,13-dimethylhexadecahydro-1H-cyclopenta[a]phenanthren-17yl)pentanamide (16)

Compound 14 (700 mg, $1.7 \mathrm{mmol})$ was dissolved in saturated $\mathrm{HCl}$ in ethanol (5 mL) and stirred at RT overnight. The solvent was evaporated and methanol $(10 \mathrm{~mL})$ was added to the residue then stirred for $1 \mathrm{~h}$. The solid was filtered and washed with methanol. The white solid was dried, and the crude product 15 (400 mg) was obtained, which was used in 
the next step without purification.

Cholic acid (408 mg, $1 \mathrm{mmol}$ ) and triethylamine $(0.12 \mathrm{~mL}, 1$ $\mathrm{mmol})$ were dissolved in dry DMF $(6 \mathrm{~mL})$. The mixture was cooled to $-15{ }^{\circ} \mathrm{C}$, and ethyl chloroformate $(0.1 \mathrm{~mL}, 1 \mathrm{mmol})$ was added. After stirring for $20 \mathrm{~min}$, compound 15 (351 mg, $1.1 \mathrm{mmol}$ ) was added to the mixture by a dropwise addition in $5 \mathrm{~mL}$ DMF. The reaction mixture was stirred at $-15{ }^{\circ} \mathrm{C}$ for $30 \mathrm{~min}$ and at RT overnight. The reaction mixture was filtered and concentrated. Subsequently, the residue was subjected to silica gel chromatography (dichloromethane/methanol, 20:1 to 5:1) to yield 16 as a white solid (300 mg, total yield: $82 \%$ ).

mp $178-180^{\circ} \mathrm{C}$.

${ }^{1} \mathrm{H}-\mathrm{NMR}\left(\mathrm{CD}_{3} \mathrm{OD}, 300 \mathrm{MHz}\right): \delta 8.24(\mathrm{~d}, 1 \mathrm{H}, \mathrm{J}=7.8 \mathrm{~Hz}), 7.46$ (d, 1H, J=7.7 Hz), 6.19 (d, 1H, J=4.1 Hz), 4.28 (m, 1H), 4.09 (m, $1 \mathrm{H}), 4.01(\mathrm{~m}, 1 \mathrm{H}), 3.89(\mathrm{~s}, 1 \mathrm{H}), 3.8(\mathrm{~m}, 3 \mathrm{H}), 3.47(\mathrm{t}, 2 \mathrm{H}, \mathrm{J}=6.4$ $\mathrm{Hz}), 2.66(\mathrm{t}, 2 \mathrm{H}, \mathrm{J}=6.2 \mathrm{~Hz}), 2.4-1.01(\mathrm{~m}, 25 \mathrm{H}), 0.98(\mathrm{~d}, 3 \mathrm{H}, \mathrm{J}=6.3$ $\mathrm{Hz}), 0.9$ (s, 1H), 0.65 (s, 1H).

${ }^{13} \mathrm{C}$ NMR (100 MHz, d ${ }^{6}$-DMSO) $\delta 172.9,172.2,162.1,154.6$, 146.7, 94.5, 87.1, 85.8, 76.2, 74.6, 71.1, 70.5, 66.4, 61.1, 46.2, 45.8, $41.6,41.4,36.5,35.4,35.2,34.9,34.5,32.5,31.8,30.8,30.4,28.5$, $27.4,26.3,22.9,22.7,17.2,12.4$.

MS (ESI): $m / z 705(\mathrm{M}+\mathrm{H})^{+}$; HRMS calcd for $\mathrm{C}_{36} \mathrm{H}_{56} \mathrm{~N}_{4} \mathrm{O}_{10} \mathrm{Na}$ : $727.3894(\mathrm{M}+\mathrm{Na})^{+}$; Found: 727.3898.

\section{Acknowledgements}

This work was financially supported by National Science \& Technology Major Project "Key New Drug Creation and Manufacturing Program" of China (№ 2009ZX09301-001).

\section{Author contribution}

Jing-kang SHEN and Dan-qi CHEN designed research; DanCHEN, Xin WANG, Lin CHEN, Jin-xue HE and Ze-hong MIAO performed research; Dan-qi CHEN and Xin WANG contributed new analytical tools and reagents; Dan-qi CHEN and Xin WANG analyzed data; and Dan-qi CHEN wrote the paper.

\section{References}

1 Pallavicini MG. Cytosine arabinoside: Molecular, pharmacokinetic and cytokinetic considerations. Pharmacol Ther 1984; 25: 207-38.

2 Rustum M, Raymakers RA. 1-ß-Arabinofuranosylcytosine in therapy of leukemia: Preclinical and clinical overview. Pharmacol Ther 1993; 56: 307-21.

3 Beumer JH, Eiseman JL, Parise RA, Florian Jr JA, Joseph E, D'Argenio DZ, et al. Plasma pharmacokinetics and oral bioavailability of 3,4,5,6-tetrahydrouridine, a cytidine deaminase inhibitor in mice. Cancer Chemother Pharmacol 2008; 62: 457-64.

4 Hsi D, Ho W. Distribution of kinase and deaminase of 1- $\beta$-D-Arabinofuranosylcytosine in tissue of man and mouse. Cancer Res 1973; 33 : 2816-20.
5 Hamada A, Kawaguchi T, Nakano M. Clinical pharmacokinetics of cytarabine formulations. Clin Pharmacokinet 2002; 41: 705-18.

6 Novotny L, Rauko P. Cytarabine conjugates with biologically active molecules and their potential anticancer activity. Neoplasma 2009; 56: $177-86$.

7 Miller LP, Pyesmany AF, Wolff L, Rogers PCJ, Siegel SE, Wells RJ, et al. Successful reinduction therapy with amsacrine and cyclocytidine in acute nonlymphoblastic leukemia in children - A report from the childrens cancer study-group. Cancer 1991; 67: 2235-40.

8 Ueda T, Nakamura T, Ando S, Kagawa D, Sasada M, Uchino H, et al. Pharmacokinetics of $N^{4}$-Behenoyl-1- $\beta$ - $D$-arabinofuranosylcytosine in patients with acute leukemia. Cancer Res 1983; 43: 3412-6.

9 Rosti G, Bonifazi F, Trabacchi E, Vivo A, BAssi S, Martinelli G, et al. A phase II study of $\alpha$-interferon and oral arabinosyl cytosine (YNK01) in chronic myeloid leukemia. Leukemia 2003; 17: 554-9.

10 Cheon EP, Hong JH, Han HK. Enhanced cellular uptake of Ara-C via a peptidomimetic prodrug, L-valyl-Ara-C in Caco-2 cells. J Pharm Pharmacol 2006; 58: 927-32.

11 Kery V, Novotny L, Tihlarik K, Haplová J, Kacuráková M, Sandula J, et al. Preparation, properties and antileukemic activity of arabinosylcytosine polysaccharide conjugates. Int J Biochem 1990; 22: 1203-7.

12 Hong $\mathrm{Cl}$, Nechaev A, West CR. Nucleoside conjugates as potential antitumor agents. 2. Synthesis and biological activity of 1-(beta-D-arabinofuranosyl)cytosine conjugates of prednisolone and prednisone. J Med Chem 1979; 22: 1428-32.

13 Sievanen E. Exploitation of bile acid transport systems in prodrug design. Molecules 2007; 12: 1859-89.

14 Enhsen A, Kramer W, Wess G. Bile acids in drug discovery. Drug Discov Today 1998; 3: 409-18.

15 Tolle-Sander S, Lentz KA, Maeda DY, Coop A, Polli JE. Increased acyclovir oral bioavailability via a bile acid conjugate. Mol Pharm 2004; 1: 40-8.

16 Geldern TW, Tu N, Kym PR, Link JT, Jae H, Lai C, et al. Liver-selective glucocorticoid antagonists: A novel treatment for type 2 diabetes. J Med Chem 2004; 47: 4213-30.

17 Gabano E, Ravera M, Osella D. The drug targeting and delivery approach applied to Pt-Antitumour complexes. A coordination point of view. Curr Med Chem 2009; 16: 4544-80.

18 Jurcek O, Wimmer Z, Svobodova H, Bennettova B, Kolehmainen E, Drasar P. Preparation and preliminary biological screening of cholic acid-juvenoid conjugates. Steroids 2009; 74: 779-85.

19 Rohacova J, Marin ML, Martinez-Romero A, Diaz L, O'Connor JE, Gomez-Lechon MJ, et al. Fluorescent benzofurazan-cholic acid conjugates for in vitro assessment of bile acid uptake and its modulation by drugs. ChemMedChem 2009; 4: 466-72.

$20 \mathrm{Hu} \mathrm{P}$, Hou S, Jin H, Zhang J, Wang L. Synthesis and stability of bile acid conjugate lamivudine as a liver target prodrug. Central South Pharmacy 2005; 3: 13-5.

21 Ju J, Gitcho MA, Casmaer CA, Patil PB, Han D, Spencer SA, et al. Potentiation of insulin-stimulated glucose transport by the AMP-activated protein kinase. Am J Physiol Cell Physiol 2007; 292: 564-72.

22 Qing $\mathrm{C}$, Miao ZH, Tong $\sqcup$, Zhang JS, Ding J. Actinomycin D inhibiting K562 cell apoptosis elicited by salvicine but not decreasing its cytotoxicity. Acta Pharmacol Sin 2003; 24: 415-21. 